\title{
Management of affected areas by the pollution of the slag and ash deposits of CET Mintia
}

\author{
Andreea Cristina Tataru ${ }^{1 *}$, Aurora Stanci $^{2}$, and Dorin Tataru ${ }^{1}$ \\ ${ }^{1}$ University of Petrosani, Department of Mechanical and Industrial Engineering and Transports, \\ Universittii street, No.20, Petrosani, Romania \\ ${ }^{2}$ University of Petrosani, Departament of Management, Environmental Engineering and Geology, \\ Universittii street, No.20, Petrosani, Romania
}

\begin{abstract}
The technological processes from the combustion of certain materials in boilers results in significant amounts of slag and ash waste. Such industries that produce waste as slag and ash as a result of the process obtain electricity in the thermoelectric power plants. The biggest environmental problems caused by the thermoelectric power plants are air pollution and landscaping. In order to reduce the pollution caused by the slag and ash deposits, they should be ecologized upon completion of the slag and ash deposition process. An environmental management system aims at finding the most effective solutions for complying with environmental protection requirements. In this case, more economic solutions are needed to comply with the legislation. In this paper we will present a method of greening the slag and ash deposits of the thermoelectric power plants Mintia and the related costs.
\end{abstract}

\section{Introduction}

In recent years, environmental issues are an integral part of the strategy of companies around the world. Each economic unit strives to achieve and demonstrate, along with economic growth, a high level of environmental protection to comply with environmental legislation.

In this context, countries with high environmental standards are interested in protecting them from competitors in countries where they are less severe.

More than ever, it is recognized that effective pollution control cannot be achieved exclusively on technological solutions but must be addressed through an environmental management system integrated with the overall management of the company.

In many countries, the implementation of environmental management systems, although a voluntary action, has succeeded in convincing not only to the obtained financial benefits (such as: identifying areas that can bring savings, increasing production efficiency, finding new markets, etc.), but also by increasing creditworthiness in obtaining bank credits, attracting investors and new beneficiaries.

\footnotetext{
* Corresponding author: andreeastanci@yahoo.com
} 
In present, the company's focus on the introduction of environmental management systems (EMS) can be found at a global level. They provide a structured and systematic way of integrating environmental issues into all aspects of a company's business.

The goal is not only to comply with environmental legislation and minimize financial risks, but also to continually improve the environmental performance, thus ensuring a good image and a number of advantages in the competitive market.

\section{Thermoelectric Mintia - Deva}

The Mintia - Deva Thermal Power Plant represents for a long time the third largest electricity generating unit in Romania. Due to the size of the installed power and the high degree of availability, safety and continuity in operation, the Mintia Thermal Power Plant is a basic source of electricity for the National Energy System.

Thermoelectric Mintia - Deva (CTE Mintia), is located in the south-eastern the Transylvania, on shore of the Mures river, $7 \mathrm{~km}$ away from Deva.

CTE Mintia is located in an area characterized by a temperate typical climate for the hills and plateaus with altitudes between $200-600 \mathrm{~m}$. The average summer temperature is $21^{\circ} \mathrm{C}$ and average winter temperature is $-1^{\circ} \mathrm{C}$. The average annual temperature is $10^{\circ} \mathrm{C}$. The average annual of the precipitation ranges around $600 \mathrm{~mm} /$ year. Atmospheric pressure varies between 962.9 mbar and 975 mbar, and relative humidity between $65-86 \%$. The wind direction is W-NW.

CET Mintia is a electrical plant of heating of cogeneration that provides electricity and heat. Works with coal as base fuel and provide heat for residents of surrounding areas.

For the storage of slag and ash resulting from the burning of coal in the Mintia thermal power plant, two slag-ash deposits are used, one located in the major bed of the Mureş River, on the right bank, on an area of approx. 67 hectare (ha) and another in the place called Valea Bejan-Târnăviţa, at approx. $4 \mathrm{~km}$ from the thermal power plant, occupying an area of approx. 80 ha.

The Mures Straight Slag and Ash Landfill is located on the right bank of the Mures River, on the abandoned loop left after the execution of the dam for industrial water capture (Figure1).

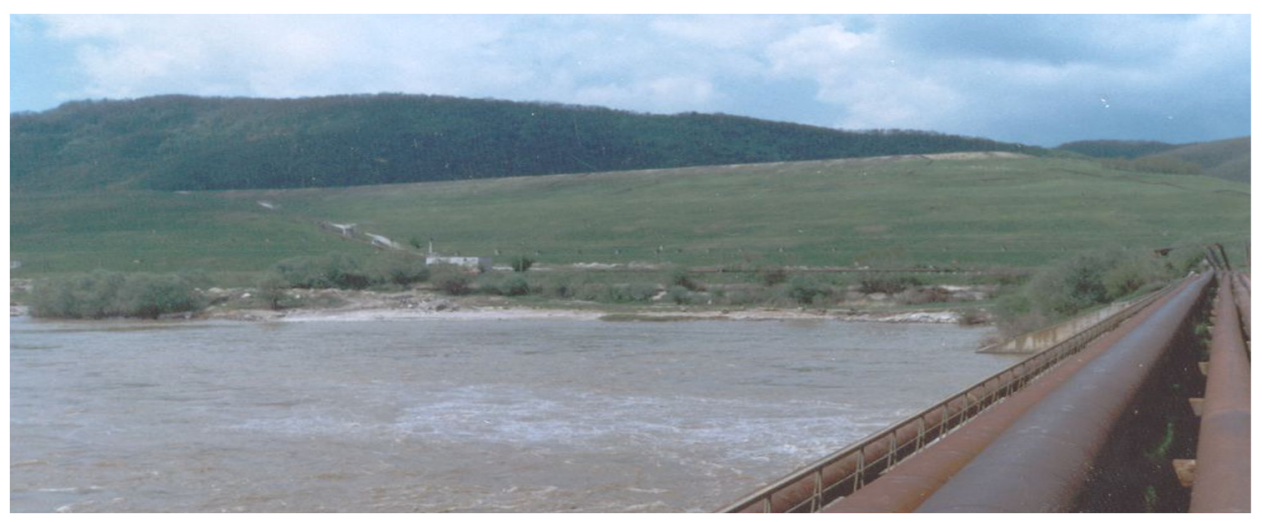

Fig. 1. The Mures Straight Slag and Ash Landfill.

The Bejan slag and ash deposit is located on the valley of the Bejan - Târnăviţa brook. (Figure 2) 


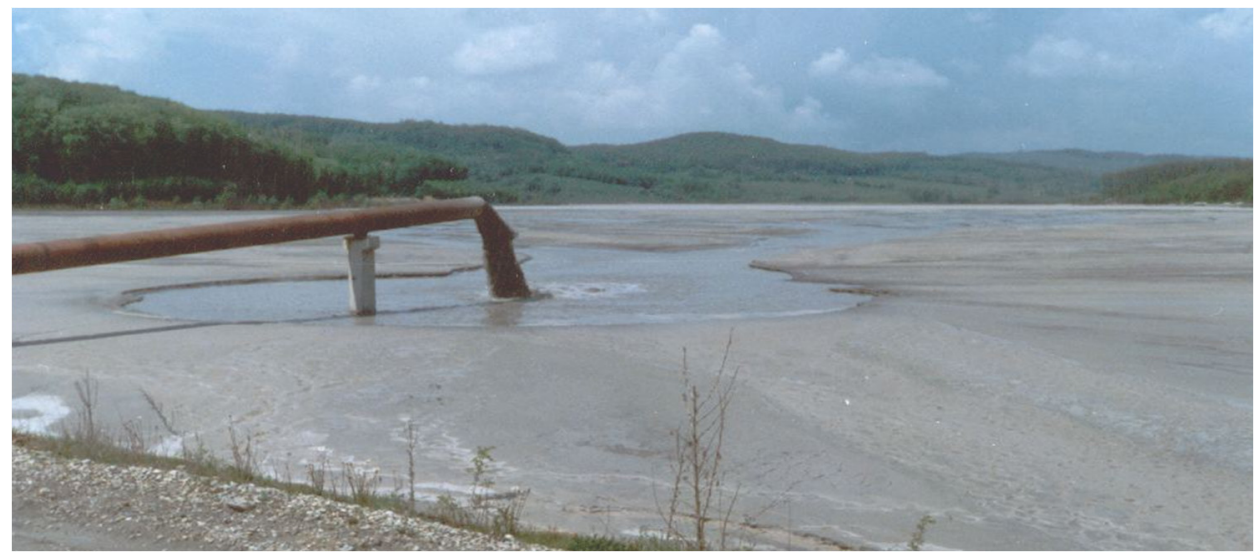

Fig. 2 The Bejan slag and ash deposit.

\section{Data and Methods}

An environmental management system has as main objective to help a company in:

- identifying and controlling the environmental aspects, impacts and risks of the company;

- meeting the environmental policy objectives and targets, including compliance with environmental legislation;

- defining a set of core principles guiding future activities addressing environmental responsibilities;

- $\quad$ establishing increases in the company's environmental performance based on a cost-benefit balance sheet;

- determining the resources needed to achieve the objectives;

- defining the responsibilities, authority and procedures to ensure the involvement of each employee of the company in reducing the negative impact on the environment;

- $\quad$ establishing an efficient communication system inside the company and providing training for the staff [1-4].

Industry throughout the world in its long existence has had and has negative effects on environmental factors. Today there is the problem of rehabilitation of areas affected by industry.

Slag and tailings dumps lead to significant problems in how they contribute to environmental pollution. These, upon completion of the filing process, should be rearranged and rendered in the natural circuit.

The tailings ponds are hydrotechnical constructions that are constructed as enclosures for tailings storage resulting from industrial production processes. They are also used for the storage of alluvial material resulting from the dredging of waterways, decoltering of accumulation lakes, etc. Slag and ash are deposited in sedimentation tailings pond.

Reintroduction in the economic circuit of land affected by anthropogenic activities is based on a complex of redevelopment works of affected areas [5].

Government Emergency Ordinance no. 195/2005 (approved by Law No. 265/2006) on Environmental Protection creates a legislative framework. This ordinance requires the redevelopment of the areas affected by anthropogenic activities after the completion of the works and the closure of the activities in the affected areas. 
Reintroduction of the land degraded by anthropogenic activities into the economic circuit is carried out on the basis of a general planting plan. It must be drafted, discussed and approved by the local community and the law enforcement bodies on the basis of which the works are planned and carried out.

The choice of ecological reuse is based on the available resources as well as the attitude of the owners and the local community.

Restoration work on degraded land must be given an economic potential. [4].

Slag and ash discharges could be ecologized by naturalistic or productive recultivation

\section{Results and Discussion}

The costs of rendering slag and ash deposits in the economic circuit are significant. For this reason, methods of productive recultivation have been proposed. By productive recultivation, greening costs can be amortized over time.

In order to reintroduce the areas in the economic circuit, it is necessary to carry out specific preparation of the land surfaces of the slag and ash deposits. These mandatory procedures are very expensive. In order to compensate over time the costs of preparing the land, we proposed to render in the economic circuit of the land areas by cultivating them with vineyards, namely the vine. In the case of productive re-cultivation with vines the costs related to the realization of the crop are:

- $\quad$ soil preparation costs,

- costs of acquiring or renting the necessary equipment,

- labor costs,

- $\quad$ purchase costs of vine cuttings, and other planting material,

- maintenance costs over the development period,

- costs for treatments.

After the planting process is completed for a period of 4 years, we will only have the costs of maintenance and treatment. After the first four years the vine begins to become productive, the costs of maintenance and treatment being covered by annual incomes. Also, every year after the development period, a damping of the greening costs will be achieved.

The costs of planting one hectare of vine in Romania are shown in Table 1. The table was made depending on the materials and equipment to be used in the three stages of greening, namely soil preparation for planting, planting and maintenance, the mandatory steps to be followed before planting vines for analysis and treatment, and labor costs. These costs are calculated according to the level of the Romanian market.

Table 1. Total costs related to the planting of one hectare (ha) of vine in Romania.

\begin{tabular}{|l|l|}
\hline \multicolumn{2}{|c|}{ Planting costs in Romania } \\
\hline Type of works & TOTAL (Euro) \\
\hline \multicolumn{1}{|c|}{$\mathbf{2}$} \\
\hline Cost for land preparation and for planting & \multicolumn{1}{|c|}{} \\
\hline Soil analyzes & 25 Euro \\
\hline Applying organic products to increase organic matter and correct Ph & 400 Euro \\
\hline Compaction to bury organic matter & 35 Euro \\
\hline Fertilization before planting & 160 Euro \\
\hline Soil preparation & 40 Euro \\
\hline Plantation & \\
\hline Marking for planting & 1000 Euro \\
\hline Planting and irrigation & 4400 Euro \\
\hline
\end{tabular}




\begin{tabular}{|l|l|}
\hline \multicolumn{1}{|c|}{$\mathbf{1}$} & \multicolumn{1}{c|}{$\mathbf{2}$} \\
\hline Instalation & \\
\hline Installing of the pillars & 2000 Euro \\
\hline Installation of the support & 130 Euro \\
\hline Installation of wire wires, stretchers, poles & 900 Euro \\
\hline Maintenance & \\
\hline Phytosanitary treatment (5 passes) & 60 Euro \\
\hline Total & 9150 Euro \\
\hline Annual maintenance costs & \\
\hline Prunning & 850 Euro \\
\hline Phytosanitary treatment (8 passes) & 142 Euro \\
\hline Total & 992 Euro \\
\hline
\end{tabular}

The costs of making a vine plantation are composed of material costs, mechanization and labor.

The cost of achieving one vineyard plantation per hectare in Romania is 9150 Euro

Once the planting process is completed, the vineyard requires careful maintenance every year. Annual maintenance concerns treatment, prunning and binding. The annual cost per hectare of vine for maintenance is 992 Euro in Romania

The costs of vine planting and maintenance can be amortized by production to the final products after four years.

In order to show that the fruits are not contaminated by the chemicals present in the soil from the tailings ponds, a series of chemical analyses were performed. The results obtained from the analyses are presented in table 2 . Analyses were performed both for grapes from vines grown in normal soil and from vines grown in soil from slag and ash deposits.

Table 2. Results of chemical analyses obtained for grapes from vines grown in normal soil and from vines grown in soil from slag and ash deposits.

\begin{tabular}{|c|c|c|c|c|c|c|c|}
\hline $\begin{array}{c}\text { Chemical } \\
\text { element }\end{array}$ & $\begin{array}{c}\mathbf{C a} \\
{[\mathbf{m g} / \mathbf{k g}]}\end{array}$ & $\begin{array}{c}\mathbf{C r} \\
{[\mathbf{m g} / \mathbf{k g}]}\end{array}$ & $\begin{array}{c}\mathbf{F e} \\
{[\mathbf{m g} / \mathbf{k g}]}\end{array}$ & $\begin{array}{c}\mathbf{M g} \\
{[\mathbf{m g} / \mathbf{k g}]}\end{array}$ & $\begin{array}{c}\mathbf{M o} \\
{[\mathbf{m g} / \mathbf{k g}]}\end{array}$ & $\begin{array}{c}\mathbf{P b} \\
{[\mathbf{m g} / \mathbf{k g}]}\end{array}$ & $\begin{array}{c}\mathbf{T i} \\
{[\mathbf{m g} / \mathbf{k g}]}\end{array}$ \\
\hline $\begin{array}{c}\text { vines grown in } \\
\text { normal soil }\end{array}$ & 5379.59 & 16.08 & 85.7 & 1687.78 & 0.08 & 1.1 & 2.72 \\
\hline $\begin{array}{c}\text { vines grown in } \\
\text { slag and ash }\end{array}$ & 5648.3 & 16.33 & 87.4 & 1723.4 & 0.09 & 1.2 & 2.53 \\
\hline
\end{tabular}

Four years after planting, the vine becomes productive. Due to the fact that the chemicals in the slag and ash are not transmitted in the fruit beyond the maximum admissible limits, they can be used.

Fruits can be sold fresh or for the production of alcoholic and non-alcoholic beverages.

Depending on the type of grape varieties chosen per hectare, between 5,000 and 10,000 liters of wine or juice can be obtained.

This type of reintroduction of the land affected by the deposits has a positive impact on the population in their vicinity. Planting, maintenance and subsequent production will create new jobs.

In the case of the greening process proposed by us through productive recultivation, it is necessary to put a layer of vegetal soil of $15-20 \mathrm{~cm}$, which would allow the reduction of the scrolling phenomenon. The costs related to this greening stage reach EUR 24,400 per hectare of land. This stage also helps in a better development of the vegetation.

Another method of covering slag and ash deposits in thermal power plants is the use of geotextiles. This method can be advantageous due to the fact that currently the availability of topsoil is very low. 
According to previous studies, the costs of greening deposits and ash by using geotextile are 59,000 EUR/ hectare.

The estimated cost of covering the clay deposits is 57800 EUR / hectare. These greening methods are not a productive greening that offers the possibility to depreciate these costs.

\section{Conclusions}

Environmental management is an important component of environmental protection.

An environmental management system aims to find the most efficient solutions for complying with the conditions imposed by legislation in the field of environmental protection.

The land areas occupied by the slag and ash deposits of the Mintia thermal power plant represent a significant land area.

Due to the high cost of redeveloping degraded land resulting from industrial activities, it is necessary to find redevelopment solutions that can be compensatted over time.

The costs of vineyard recultivation of slag and ash deposits are amortized after 4 years of planting.

Planting one hectare of vine may reach costs of 9150 Euro in Romania.

The cost is composed of materials and equipment to be used in the three stages of greening, namely soil preparation for planting, planting and maintenance, analysis and treatment, as well as the costs necessary for labor.

The costs presented are calculated according to the level of the Romanian market.

The location of the slag and ash ponds of the Mintia thermal power plant is also climatically favorable for the development of vineyards.

After the first four years, the vines start to become productive, the maintenance and treatment costs being covered by the annual income.

\section{References}

1. E. Škorecová, A. Látečková, Monitoring costs of material flows - a new trend in environmental management and accounting, International Scientifis Conference Mmanagerial trends in the development of enterprises in globalization era, (2017)

2. L. Dobošová, D. Čeryová, M. Urbánová, M. Jamrich, Attitude of Agribusiness Entities to Green Management in Slovak Republic, International Scientifis Conference Mmanagerial trends in the development of enterprises in globalization era, (2017)

3. V. Rojanschi, F. Bran, F. Grigore, Elemente de economia si managementul mediului (Ed. Economical PH, Bucharest, 2004)

4. D. Tataru, A.C. Tataru, A. Stanci, S.M. Radu, Landscaping solutions of tailings ponds of Thermoelectric Power Plants using vine plants, 7th International Multidisciplinary Symposium „Sustainable Development Through Quality and Innovation in Engineering and Research”, (2016)

5. D. Tataru, A. C. Tataru, A. Stanci, S. M. Radu M. S. Nan, Proceedings of The Symposion SESAM 2015 2, 501-506 (2015) 